\title{
Studying Phytochemical Features of Three Asteraceae Herbs Growing Wild in Kazakhstan
}

\author{
Zhadyra B. Ashirova ${ }^{1}$ (1) \\ Zhenis Z. Kuzhantaeva ${ }^{2}$ (D) \\ Zhanna T. Abdrassulova ${ }^{2}$ (D) \\ Gulsana Z. Shaimerdenova ${ }^{3}$ \\ Gulshat K. Atanbaeva ${ }^{2}$ \\ ${ }^{1}$ Kazakh National Women's Teacher Training University, Kazakhstan. \\ ${ }^{2}$ Al-Farabi Kazakh National University, Kazakhstan. \\ ${ }^{3}$ M.Kh. Dulati Taraz Regional University, Kazakhstan.
}

\begin{abstract}
This study aimed to evaluate the phytochemical features of medicinal species of the Asteraceae family, their mineral elements, antioxidants, vitamins, and amino acids. The species studied included common yarrow (Achillea millefolium L.), common chicory (Cichorium intybus L.), and German chamomile (Chamomilla recutita (L.) Rauschert) collected in the Ile Alatau Mountain (Trans-Ili Alatau), Kazakhstan. The plants were harvested in July 2019-July 2020 during their flowering. The article's scientific novelty lies in the conceptual research of phytochemical and morphological features of medicinal species with a maximum content of biologically active substances and high antioxidant activity, which can be a basis for creating innovative functional food products enriched with natural antioxidants. The article describes a new idea to display a very high concentration and diversity of vitamins ( 8 types), mineral elements ( 8 types), antioxidants, and amino acids (13 types) in the flowers of C. intybus L., Ch. recutita L., A. millefolium L.
\end{abstract}

Keywords: Phytochemistry, Asteraceae family, Achillea millefolium L., Cichorium intybus L. (chicory), Chamomilla recutita (L.) Rausch.

\section{INTRODUCTION AND OBJECTIVES}

Plants are a rich source of bioactive compounds widely used due to their healing and cosmetic properties. The healthpromoting activities of many plant-derived compounds have been confirmed by in vitro and in vivo studies (Ali et al., 2017; Gaweł-Bęben et al., 2020a, 2020b; Hormozi and Baharvand, 2019).

Asteraceae family (also called Compositae) consists of various important medicinal plants with a wide range of biological properties and interesting phytochemical constituents (Jeffrey, 2007).

Asteraceae Dumort (commonly referred to as the aster, daisy, composite) is an extensive and widespread family of flowering plants. The number of species reaches 30000 that belong to 1600-1700 genera worldwide, except glaciers (Funk et al., 2009). Asteraceae is the largest family in the flora of
Kazakhstan; there are 883 species from 146 genera (GawełBęben et al., 2020a; Baitenov, 2019; Abdulina, 2020).

Achillea millefolium is native to Europe and Western Asia, widespread in temperate regions (Gubanov, 2004). The species has anti-inflammatory (chamazulenes and prochamazulenes, apigenin, salicylic acid), hemostatic (betonicine), and spasmolytic (flavonoids) effects. Numerous studies are dedicated to $A$. millefolium (Aronson, 2016; Hedayat \& Lapraz, 2019; Romm, 2010; Shah \& Peethambaran, 2018 and many others).

Cichorium intybus is native to Europe, central Russia, and western Asia. Currently, it is well naturalized beyond the native range worldwide (Závada et al., 2017; Queensland Government, 2019). This species was formerly cultivated as a medicinal plant, but more recently, they have been grown as an ornamental and coffee substitute (Wu et al., 2011). The roots of the C. intybus are widely used as a traditional herbal remedy and have antihepatotoxic properties. Also, the plant is widely used in the food industry. 
Chamomilla recutita is native to southern and eastern Europe and western Asia. It is widely cultivated in Europe and has been introduced in some Asian countries, Argentina and Egypt, to produce its essential oil. Nowadays, the plant can be found on all continents. The flowers have anti-inflammatory and spasmolytic properties (Evans, 2009), which explains their use in herbal remedies since ancient Egypt, Greece, and Rome. In addition, the essential oil in the flower heads contains azulene and is used in perfumery: cosmetic creams, hair preparations, skin lotions, toothpaste, baby massage oil, and soap.

The bioactive ingredients of $A$. millefolium and A. biebersteinii Afan. from Kazakhstan (Pavlodar region) were studied for cosmetic use. The hydroglycolic extracts from A. biebersteinii showed a more diverse phytochemical composition. The extracts from the A. millefolium also have valuable properties in cosmetic use and have been demonstrated in a broad range of scientific studies (Gaweł-Bęben et al., 2020).

Recent studies on Cichorium intybus have found some of the important constituents, such as caffeic acid derivatives, phenylacetic acid esters, fructooligosaccharides, flavonoids, coumarins, polyphenol, cichoriosides, sonchuside A, ixerisosides, magnolialide, eudesmanolides, bitter sesquiterpene lactones, insulin, and vitamins (El-Lakany et al., 2004; Hussain et al., 2011; Kumari et al., 2012). Satmbekova et al. (2018) reported the isolation and characterization of one new $28 \beta$-hydroxytaraxasterol besides six known compounds from the aerial parts of C. intybus.

The interest in studying the species of the Asteraceae family worldwide, including in Kazakhstan, is quite understandable. Compositae species play a role in the country's vegetation cover; they are important forage plants in spring and autumnwinter pastures. The most common representatives of the Asteraceae family in Kazakhstan include Achillea millefolium L., Cichorium intybus L., Chamomilla recutita (L.) Rausch.

Asteraceae species are highly variable inhabiting territories with different types of landscapes, different ecological conditions (high mountains, forests, mountain steppes, steppes, and deserts). The most characteristic feature of many species from different genera of this family is intraspecific polymorphism: instability, variability of morphological characters, which up to the present time determine different understanding of the volume of many species. In this regard, the determination of the family species is a very difficult matter; in many cases, it can only be carried out by specialists. The morphology and biochemistry of Compositae in Kazakhstan have not been studied in detail before.

This article deals with Asteraceae species that are most common on the earth, namely on the slopes of the Ile Alatau in Kazakhstan: Achillea millefolium L., Cichorium intybus L.,
Chamomilla recutita (L.) Rausch and Achillea millefolium L., whose properties were studied by phytochemical analysis. The material was collected in the Ile Alatau Mountain, Kazakhstan. Plant species were harvested in July 2019-July 2020 during the plant flowering (Figure 1).

These plants are widely used due to their benefits in medicine, perfumery, and cooking. Determining the phytochemical composition of plants is complex and timeconsuming. However, scientific and technological progress and development of physicochemical analysis of natural compounds allow for in-depth study of nature, most in the chemistry of natural compounds. The methods are effective because most of the samples analyzed are additives.

This study covers mineral elements $(\mathrm{K}, \mathrm{Mg}, \mathrm{Fe}, \mathrm{Cu}, \mathrm{Na}$, $\mathrm{Ca}, \mathrm{F}, \mathrm{Zn}$ ), fat-soluble vitamins ( $\alpha$-tocopherol, $\beta$-tocopherol, $\gamma$-tocopherol, and $\delta$-tocopherol), water-soluble vitamins (B1, B2, B6, C, B3, B5, B9), 13 types of amino acids (arginine, lysine, tyrosine, phenylalanine, histidine, leucine + isoleucine, methionine, valine, proline, threonine, serine, alanine, glycine) and antioxidants. Vitamin $\mathrm{C}$ is an effective substance for improving the immune system. The presence of $\mathrm{B}$ vitamins also contributes to the human body becoming less susceptible to viruses.

The choice of the object for the study and the goal-setting was determined by the therapeutic and phytochemical properties of the plants:

Achillea millefolium L., Cichorium intybus L., Chamomilla recutita (L.) Rausch are the most common types of medicinal plants on the slopes of the Ile Alatau in Kazakhstan.

Achillea millefolium L. contains essential oils of achilleine, camphor, acetic acid, valerian, aconite, ascorbic acid, vitamins $\mathrm{C}$ and $\mathrm{K}$, and phytoncides. It has hemostatic and vasodilating properties. It is used against bleeding from the lungs, hemorrhoids, peptic ulcer disease. It grows in the forest, forest-steppe, steppe, meadowlands, deserts, fields, and roadsides. In Kazakhstan, it grows in Dzhungarsky, Ili Alatau, Kungey Alatau, Chu-Ili mountains, Western Tien Shan, Altai, Tarbagatai, and other regions.

Cichorium intybus L. Common chicory (Cichórium intybus L.) has not been studied properly, available in sufficient quantities in Kazakhstan. It is possible to isolate inulin (20-40\%) from chicory roots; this polysaccharide increases the sensitivity of pancreatic cells to glucose and stimulates insulin production. Chicory was established to contain intybin glucoside, aromatic substances, $15.8 \%$ ascorbic acid, $10-20 \%$ mucous substances, levulose, choline, pentosans; flowers have chicorin glucoside; foliage contains inulin, ascorbic, and chicoric acids, seeds contain inulin and protocatechuic aldehyde. In addition, the mucous substances (lactucin and lactobacterin) are isolated from chicory laticifers (Wu et al., 2011). 
Stems, leaves, flowers, seeds, and roots of the plant are vegetal medicinal raw stuff. Chicory has bactericidal and astringent properties. It is an excellent antimicrobial and antiviral agent. A warm chicory brew kills germs that cause inflammation. Herbal preparations of chicory improve the metabolic processes, functioning of the thyroid gland and remove excess substances from the body. They exert an antiinflammatory effect on the gastrointestinal tract, increase the body's ability to feel the effects of a particular substance. They have an analgesic effect and treat the accumulation of fatty compounds in the walls of blood vessels, disorders of mineral metabolism, kidney and gallbladder diseases, and gout (inflammatory damage to the joints due to impaired metabolism of uric acid in the body). In combination with raw materials of other plants, chicory can be applied for gastrotherapy and treating enteropathy, splenopathy, and pancreopathy. It is used to strengthen appetite and treat paroxysmal nervous disease (hysteria), general weakness, fatigue, hepatic disorders, cholecystitis, biliary and vesical dysfunctions (dyskinesia), gastritis, colitis, and early-stage diabetes mellitus. Chicory is well-known among people as a herbal remedy for the liver (Lavrenova \& Lavrenov 2008).

The entire plant has numerous applications in the food industry, as well. Its dried roots have long been used as a coffee substitute or adulterant in coffee powder. The young leaves can be added to salads and vegetable dishes, while chicory extracts are used to produce invigorating beverages. Chicory has long been recognized as a melliferous plant, it is in bloom for extended periods from June to October, and its flowers are rich in pollen and nectar. That is why bees value chicory, producing yellowish-green honey from it.

Wild chicory is used for winter forage for ruminant livestock exceptionally because of its nutritive value.

Chamomilla recutita (L.) Rauschert is famous mainly for its anti-inflammatory, hemostatic, antiseptic, spasmolytic and mildly sudorific, carminative, choleretic, sedative, and healing effect. Chamomile contains many therapeutically interesting and active compound classes: sesquiterpenes, flavonoids, coumarins, and polyacetylenes are considered the most important constituents. Flower heads are used internally mainly as a tisane for disturbance of the stomach associated with pain, sluggish digestion, diarrhea, and nausea; more rarely and very effectively for inflammation of the urinary tract and painful menstruation. Externally, the drug in powder form may be applied to wounds slow to heal, for skin eruptions and infections, such as shingles and boils, hemorrhoids, and inflammation of the mouth, throat, and eyes (Singh et al., 2011). In Kazakhstan, this plant grows in the Ile Alatau, Dzhungarsky, and Kungeysky Alatau Mountains.

Samples. A. millefolium, C. intybus, C. recutita flowers were collected in the Ile Alatau Mountains to conduct phytochemical analyses of the species.
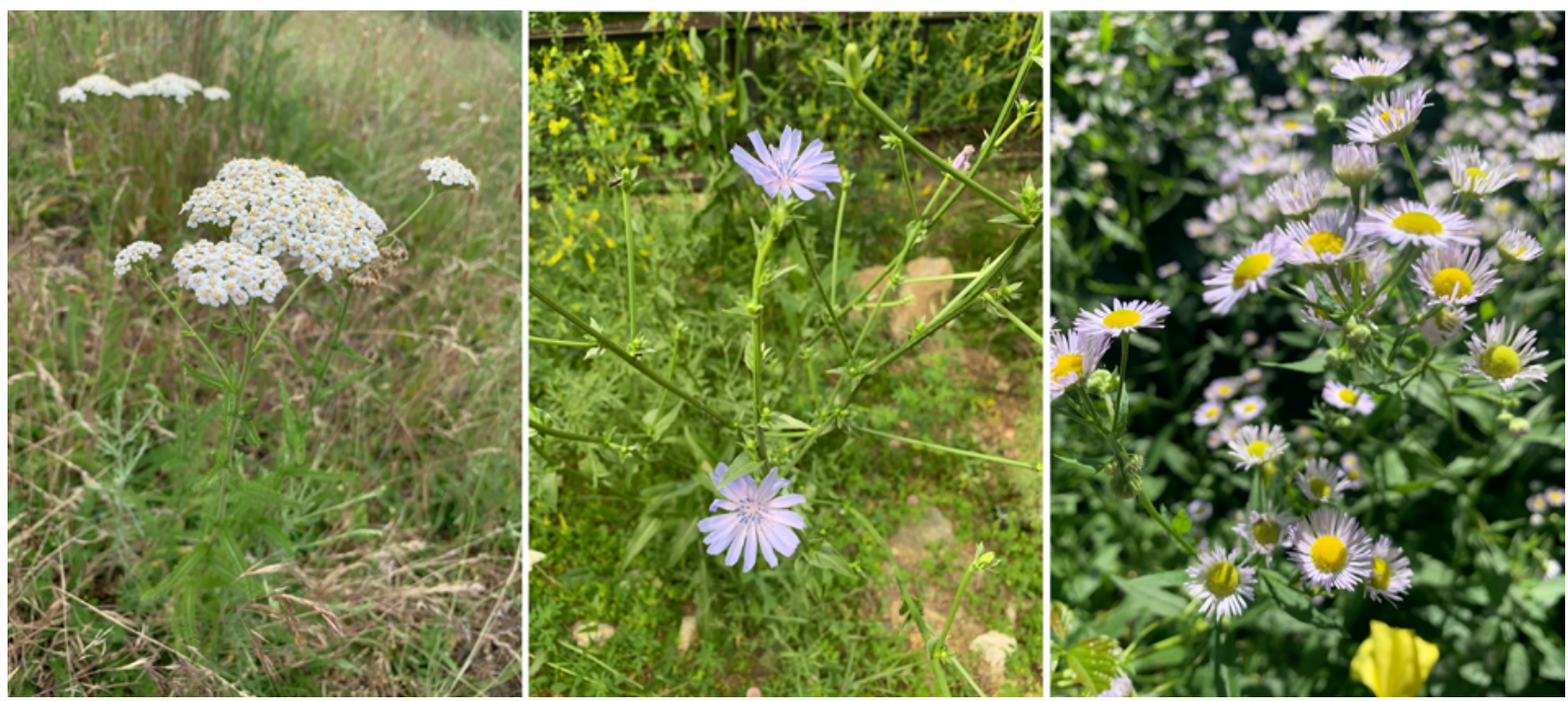

Figure 1. Achillea millefolium L., Cichorium intybus L., Chamomilla recutita (L.) Rausch.

Source: Photos were taken by the authors of the article in 2019-2020 in Kazakhstan during the flowering period of plants. 
The phytochemical features of medicinal species of the Asteraceae family and the composition of mineral elements, antioxidants, vitamins, and amino acids were investigated to implement the research objective:

- Studying and analyzing the morphological and phytochemical properties of Asteraceae species and determining the medicinal properties of these plants for their correct usage as first aid, curing many diseases, and looking great without using chemical tablets.

\section{MATERIALS AND METHODS}

\subsection{Experimental procedures}

Plants were harvested before or during the plant's flowering, carefully picking them off by hand and trying not to damage them. For this study, we used the roots, stems, leaves, and flowers of various types. Raw plants quickly deteriorate, and medicinal substances are destroyed, and the color of the plant changes. Therefore, the plants must be dried immediately after harvest while observing the basic rules. Raw plants were dried in special dryers at a temperature of $40-60^{\circ} \mathrm{C}$. Before drying, the raw materials were carefully sorted, impurities and spoiled specimens were removed. The flowers were dried by first separating them from the leaves and stems. Each medicinal plant has its own preparation time. At this time, it accumulates as many useful substances as possible, which determines its healing effect. The mineral composition of the species was determined by atomic absorption spectrometry (AAS). The spectroscopic method is based on the interaction of matter with electromagnetic radiation.

\subsection{Mineral composition determination by atomic absorption spectrometry}

The atomic absorption analysis method is most developed for determining the elemental composition of liquid samples (Beizel, 2008). Minerals were determined by the atomic absorption method under M-30 178-96 standard.

\subsection{Amino acids identification}

Amino acids were determined under M 04-38-2009 standards. The methodology was intended for the determination of all 20 proteinogenic amino acids in combined feed and the feedstock for their production: arginine, lysine, tyrosine, phenylalanine, leucine, and isoleucine (in total), methionine, valine, proline, threonine, serine, alanine, glycine, cystine, tryptophan, aspartic, and glutamic acid. Because asparagine and glutamine are quantitatively hydrolyzed to aspartic and glutamic acids, respectively, during the decomposition of samples, the data on the content of aspartic and glutamic acids represent the total content of these acids and the corresponding amides.

The method is based on the decomposition of samples by acidic or (only for tryptophan) alkaline hydrolysis to convert amino acids into free forms, obtaining amino acid phenylthiohydantoine (PTH) derivatives, their further distribution, and quantification by capillary electrophoresis. Detection was carried out in the UV region of the spectrum at a wavelength of $254 \mathrm{~nm}$. Analysis temperature: $30^{\circ} \mathrm{C}$. Wavelength: 254. Stage 1. Time $1079 \mathrm{sec}$, Voltage $25 \mathrm{kV}$. Calculation method: Absolute graduation.

\subsection{Vitamin determination}

In this study, the amount of fat-soluble vitamin E ( $\mathrm{mg} / 100 \mathrm{~g})$ was determined by chromatography under the EN 12822-2014 standard.

All other vitamins have been determined in compliance with the M-04-41-2005 standard.

Analysis temperature: $30^{\circ} \mathrm{C}$. Wavelength: 200 . Calculation method: Absolute graduation.

Stage 1. Time $899 \mathrm{sec}$, Voltage $25 \mathrm{kV}$. Pressure 0 mbar. Stage 2. Time $300 \mathrm{sec}$, Voltage $25 \mathrm{kV}$. Pressure $50 \mathrm{mbar}$. During the study, 378 samples were taken and analyzed. The analysis was carried out in three biological $(\mathrm{n}=3)$ and at least three analytical replicates. The data obtained were processed statistically and presented as the arithmetic mean values and their standard errors. The statistical significance of the differences between the options was determined using the Student's $\mathrm{t}$-test $(\mathrm{p} \leq 0.05)$. Correlation analysis was performed using Pearson's test.

The species studied were: common yarrow (Achillea millefolium L.), common chicory (Cichorium intybus L.), and German chamomile Chamomilla recutita (L.) Rausch. Phytochemical analysis of leaves of various types was performed following the previously described technique (Ashirova et al., 2018, 2019; Kyrbassova et al., 2018). The collected foliage parts were air-dried, finely ground, and passed through a 0.5 $\mathrm{mm}$ sieve. The prepared samples with approximately $8.7 \%$ moisture content were stored in dry containers for further use. The mineral composition of the species was determined by atomic absorption spectrometry (AAS). The identification of amino acids was carried out by a method based on the decomposition of samples by acidic or alkaline (only for tryptophan) hydrolysis to convert amino acids into free forms, their further distribution, and quantitative determination using capillary electrophoresis. The amount of fat-soluble vitamin $\mathrm{E}$ $(\mathrm{mg} / 100 \mathrm{~g})$ was determined by applying chromatography. The total proportion of polyphenolic compounds was determined using the Folin-Chocalteu reagent with antioxidant activity. 


\section{RESULTS AND DISCUSSION}

As shown in Table 1, potassium was found in minimal amounts in the common chicory flowers ( $124.7 \mathrm{mg})$, in large amounts $(13869.1 \mathrm{mg})$ in the common yarrow flowers. The magnesium content in the common chicory flowers $(485.15 \mathrm{mg}$ ) was the highest, and the minimum amount was found in the German chamomile flowers $(183.46 \mathrm{mg})$. Iron was found in large quantities $(73.317 \mathrm{mg})$ in common yarrow flowers. The copper content in all plant species was insignificant. The largest sodium content was revealed in German chamomile $(65.1 \mathrm{mg})$, and chicory showed the maximum calcium content $(1130.66 \mathrm{mg})$. The minimum fluor content is in the chamomile flower $(41.75 \mathrm{mg})$, and the maximum content was detected in the yarrow $(660.3 \mathrm{mg})$. The maximum amount of zinc was found in the common chicory flowers $(2.996 \mathrm{mg})$.

Natural $\alpha$-tocopherol (vitamin E) and other substances increase the stability of food products containing fats and vitamins. Chamomile flowers showed no of $\beta-, \gamma$ - and $\delta$-tocopherol, they contain only a-tocopherol of vitamin E at a dose of $0.11 \mathrm{mg}$. No varieties $\gamma$-tocopherol were found in all Asteraceae species flowers (Table 2).

The research results showed a high antioxidant activity of Asteraceae species as oxidation inhibitors; in particular, this research revealed that the antioxidant activity of the common yarrow flowers is higher than that of other species (Table 3).

As shown in Table 4, Vitamin B1 was not found in common yarrow and chicory. Vitamins B2, B6 were present in all species in small quantities. Vitamin B6 was found in German chamomile at a dose of $0.0093 \mathrm{mg}$, which is lower than in other species. German chamomile flowers contain no vitamins C, B3, B5. Vitamin B9 was not found in common yarrow.

Twelve common amino acids that make up the proteins detected in the Asteraceae species under study differ only in the lateral groups. It is possible to calculate the number of amino acids in the molecular protein weight (10a: $120=833$ ) (As shown in Table 5.).

Table 1. Composition of mineral elements in Asteraceae species flowers (mg / $100 \mathrm{~g})$.

\begin{tabular}{cccccc} 
No & $\begin{array}{c}\text { Mineral elements } \\
\text { Mg/ } 100 g\end{array}$ & $\begin{array}{c}\text { (Achillea millefolium L.) } \\
\text { Flowers }\end{array}$ & $\begin{array}{c}\text { Cichorium } \\
\text { intybus L. Flowers }\end{array}$ & $\begin{array}{c}\text { Chamomilla recutita (L.) Rausch. } \\
\text { Flowers }\end{array}$ & $\begin{array}{c}\text { Type of the method } \\
\text { applied }\end{array}$ \\
\hline 1 & $\mathrm{~K}$ & $13869.1 \pm 15.95$ & $124.7 \pm 2.9$ & $6672.8 \pm 7.67$ & AAS \\
2 & $\mathrm{Mg}$ & $339.62 \pm 3.40$ & $485.15 \pm 2.96$ & $183.46 \pm 2.11$ & AAS \\
3 & $\mathrm{Fe}$ & $73.317 \pm 0.84$ & $29.256 \pm 0.34$ & $26.8355 \pm 0.31$ & AAS \\
4 & $\mathrm{Cu}$ & $0.161 \pm 0.019$ & $0.140 \pm 0.016$ & $0.343 \pm 0.039$ & AAS \\
\hline 5 & $\mathrm{Na}$ & $9.8 \pm 0.12$ & $16.5 \pm 0.20$ & $65.1 \pm 0.78$ & AAS \\
6 & $\mathrm{Ca}$ & $794.82 \pm 9.528$ & $1130.66 \pm 13.56$ & $890.15 \pm 10.68$ & AAS \\
\hline 7 & $\mathrm{~F}$ & $660.3 \pm 7.26$ & $58.75 \pm 0.73$ & $41.75 \pm 0.75$ & Phacoemulsification \\
8 & $\mathrm{Zn}$ & $2.487 \pm 0.029$ & $2.996 \pm 0.034$ & $2.440 \pm 0.028$ & AAS \\
\hline
\end{tabular}

Source: Compiled by the authors

Table 2. Physicochemical indicators of vitamins in Asteraceae species flowers (mg/100 g).

\begin{tabular}{|c|c|c|c|c|c|}
\hline No & $\begin{array}{c}\text { Lipid soluble vitamins } \\
\text { mg/ } 100 \mathrm{~g} \\
\text { Vitamin } E\end{array}$ & $\begin{array}{c}\text { Achillea millefolium } \mathrm{L} . \\
\text { Flowers }\end{array}$ & $\begin{array}{l}\text { Cichorium intybus L. } \\
\text { Flowers }\end{array}$ & $\begin{array}{l}\text { Chamomilla recutita (L.) } \\
\text { Rausch. } \\
\text { Flowers }\end{array}$ & The method applied \\
\hline 1 & $\alpha$ - tocopherol & $1.77 \pm 0.001$ & $1.28 \pm 0.001$ & $0.11 \pm 0.01$ & \multirow{4}{*}{$\begin{array}{l}\text { Chromatographic } \\
\text { method } \\
\text { EN 12822-2014. }\end{array}$} \\
\hline 2 & $\beta$-tocopherol & $0.077 \pm 0,001$ & $0.13 \pm 0.015$ & Not found & \\
\hline 3 & $\gamma$ - tocopherol & Not found & Not found & Not found & \\
\hline 4 & $\delta$ - tocopherol & $0.043 \pm 0.001$ & $0.12 \pm 0.001$ & Not found & \\
\hline
\end{tabular}

Source: Compiled by the authors

Table 3. Antioxidant activity of the studied species (mg/ 100g).

\begin{tabular}{cccccc} 
No & $\begin{array}{c}\text { Antioxidant activity } \\
\text { mg/ } 100 g\end{array}$ & $\begin{array}{c}\text { Achillea millefolium } \mathrm{L} . \\
\text { Flowers }\end{array}$ & $\begin{array}{c}\text { Cichorium intybus L. } \\
\text { Flowers }\end{array}$ & $\begin{array}{c}\text { Chamomilla recutita } \\
\text { (L.) Rausch Flowers }\end{array}$ & The method applied \\
\hline 1 & Antioxidant activity & $158.27 \pm 3.01$ & $88.99 \pm 0.99$ & $56.19 \pm 0.96$ & Color-Yauza device \\
\hline
\end{tabular}

Source: Compiled by the authors 
Table 4. Vitamin analysis of Asteraceae species flowers harvested on the Ile Alatau Mountain.

\begin{tabular}{cccccc} 
No & $\begin{array}{c}\text { Vitamins } \\
m g / 100 g\end{array}$ & $\begin{array}{c}\text { Achillea millefolium } \mathrm{L} \text {. } \\
\text { flowers }\end{array}$ & $\begin{array}{c}\text { Cichorium } \\
\text { intybus L. flowers }\end{array}$ & $\begin{array}{c}\text { Chamomilla recutita (L.) Rausch } \\
\text { flowers }\end{array}$ & The method applied \\
\hline 1 & $\mathrm{~B}_{1}$ (thiamine chloride) & Not found & Not found & $0.0017 \pm 0.00034$ & \\
\hline 2 & $\mathrm{~B}_{2}$ (riboflavin) & $0.052 \pm 0.01$ & $0.14 \pm 0.027$ & $0.43 \pm 0.18$ \\
\hline 3 & $\mathrm{~B}_{6}$ (pyridoxin) & $0.074 \pm 0.031$ & $0.048 \pm 0.02$ & $0.0093 \pm 0.0019$ & Not found \\
\hline 4 & $\mathrm{C}_{\text {(ascorbic acid) }}$ & $0.36 \pm 0.072$ & $0.021 \pm 0.0041$ & Not found & \\
\hline 5 & $\mathrm{~B}_{3}$ (pantothenic acid) & $0.32 \pm 0.011$ & $0.21 \pm 0.071$ & Not found & \\
\hline 6 & $\mathrm{~B}_{5}$ (nicotinic acid) & $0.068 \pm 0.014$ & $0.076 \pm 0.015$ & $0.0048 \pm 0.0016$ & \\
\hline 7 & $\mathrm{~B}_{9}$ (folic acid) & Not found & $0.0059 \pm 0.0011$ & \\
\hline
\end{tabular}

Source: Compiled by the authors

Table 5. Amino acid composition of Asteraceae species flowers (\%).

\begin{tabular}{|c|c|c|c|c|c|}
\hline No & $\begin{array}{c}\text { Amino acid } \\
\%\end{array}$ & $\begin{array}{c}\text { Achillea millefolium } \mathrm{L} . \\
\text { flowers }\end{array}$ & $\begin{array}{l}\text { Cichorium intybus L. } \\
\text { flowers }\end{array}$ & $\begin{array}{l}\text { Chamomilla recutita } \\
\text { (L.) Rausch flowers }\end{array}$ & $\begin{array}{c}\text { The method } \\
\text { applied }\end{array}$ \\
\hline 1 & arginine & $0.25 \pm 0.10$ & $0.16 \pm 0.06$ & $0.19 \pm 0.07$ & \multirow{13}{*}{ M-04-38-2009 } \\
\hline 2 & lysine & $0.20 \pm 0.07$ & $0.06 \pm 0.02$ & $0.09 \pm 0.03$ & \\
\hline 3 & tyrosine & $0.13 \pm 0.04$ & $0.03 \pm 0.01$ & $0.06 \pm 0.02$ & \\
\hline 4 & phenylalanine & $0.19 \pm 0.06$ & $0.05 \pm 0,01$ & $0.10 \pm 0.03$ & \\
\hline 5 & histidine & $0.05 \pm 0.02$ & $0.02 \pm 0.01$ & $0.08 \pm 0.04$ & \\
\hline 6 & leucine + isoleucine & $0.25 \pm 0.07$ & $0.07 \pm 0.02$ & $0.10 \pm 0.03$ & \\
\hline 7 & methionine & $0.03 \pm 0.01$ & $0.01 \pm 0.003$ & $0.02 \pm 0.007$ & \\
\hline 8 & valine & $0.23 \pm 0.09$ & $0.07 \pm 0.03$ & $0.13 \pm 0.05$ & \\
\hline 9 & proline & $0.61 \pm 0.16$ & $0.10 \pm 0.02$ & $0.14 \pm 0.04$ & \\
\hline 10 & threonine & $0.19 \pm 0.08$ & $0.06 \pm 0.02$ & $0.09 \pm 0.04$ & \\
\hline 11 & serine & $0.19 \pm 0.05$ & $0.06 \pm 0.01$ & $0.09 \pm 0.02$ & \\
\hline 12 & alanine & $0.20 \pm 0.05$ & $0.06 \pm 0.01$ & $0.08 \pm 0.02$ & \\
\hline 13 & glycine & $0.19 \pm 0.06$ & $0.05 \pm 0,01$ & $0.09 \pm 0.03$ & \\
\hline
\end{tabular}

Source: Compiled by the authors

Determining the phytochemical composition of the studied species is very important in the pharmaceutical industry. According to the general quantitative phytochemical analysis results, this research makes it possible to compare these plant species with other species. In addition, phytochemical analysis is important in the treatment of people in the pharmaceutical industry.

\section{CONCLUSIONS}

Based on the research results, the following conclusions can be drawn:

Potassium was found in minimal amounts in the Cichorium intybus L. flower (124.7 mg) and maximum amounts (13.869 $\mathrm{mg}$ ) in the Achillea millefolium L.

The magnesium content was the highest in the common chicory flowers $(485.15 \mathrm{mg})$ and the lowest in the Chamomilla recutita (L.) Rausch. (183.46 mg).

Iron content has the highest $(73.317 \mathrm{mg})$ in Achillea millefolium $\mathrm{L}$. flowers.

Zinc content has the highest $(2.996 \mathrm{mg})$ in Cichorium intybus L. flowers.
No varieties $\gamma$-tocopherol were found in all Asteraceae species flowers. Chamomile flowers contain only $a$-tocopherol of vitamin $\mathrm{E}$ at a dose of $0.11 \mathrm{mg}$.

The results of these studies have demonstrated a high antioxidant activity of Asteraceae species as oxidation inhibitors; in particular, the antioxidant activity of the common yarrow flowers is higher than that of other species

Vitamins B2, B6 were found in all species in small quantities. Vitamin B6 was found in Chamomilla recutita (L.) Rausch at the lowest dose of $0.0093 \mathrm{mg}$ compared to other species. Chamomilla recutita (L.) Rausch flowers contain no vitamins C, B3, B5. Vitamin B9 was not found in common yarrow.

The practical significance of the article is determined by the fact that the authors display very high concentration and diversity of vitamins (8 types), mineral elements (8 types), antioxidant activity, and amino acids (13 types) in the flowers of C. intybus L., Ch. recutita L., A. millefolium L. Studies of the biochemical and morphological characteristics of species of the Asteraceae family made it possible to describe the morphological features in more detail. Studying the composition of the vitamin and minerals enabled to draw 
conclusions about which species are rich in these and have a higher importance in medicine and agriculture. In further studies, we plan to study the anatomical structure of the roots, stems, leaves, flowers of A. millefolium L., C. intybus L., Ch. recutita (L.) Rausch.

\section{ACKNOWLEDGEMENTS}

The authors of the article express gratitude to the Research Center of Almaty Technological University, during the research were used laboratory equipment and reagents for the determination of minerals, fats and water-soluble elements.

\section{SUBMISSION STATUS}

Received: 09 Aug. 2021

Accepted: 29 Sep. 2021

Associate editor: Rodrigo Studart Corrêa (1)

\section{CORRESPONDENCE TO}

\section{Zhanna T. Abdrassulova}

Al-Farabi Avenue 71 Almaty 050040, Kazakhstan

e-mail: zhanna.abdrassulova@bk.ru

\section{AUTHORS' CONTRIBUTIONS}

Zhadyra B. Ashirova: Conceptualization (Lead); Funding acquisition (Supporting); Investigation (Lead); Supervision (Lead); Validation (Lead); Visualization (Lead); Writingoriginal draft (Lead); Writing-review \& editing (Lead).

Zhenis Z. Kuzhantaeva: Conceptualization (Equal); Resources (Lead); Validation (Lead); Writing-review \& editing (Equal).

Zhanna T. Abdrassulova: Formal analysis (Lead); Investigation (Lead); Methodology (Lead); Software (Supporting); Supervision (Lead); Validation (Lead); Visualization (Lead); Writingoriginal draft (Lead); Writing-review \& editing (Lead).

Gulsana Z. Shaimerdenova: Formal analysis (Lead); Methodology (Lead); Software (Supporting).

Gulshat K. Atanbaeva: Visualization (Lead); Writing-original draft (Lead).

\section{REFERENCES}

Abdulina SA. Checklist of vascular plants of Kazakhstan. Almaty: Science, 2020

Adem G, Şaban KM, Turanc A, Usanmaz B. Determination of antioxidant enzyme activity and phenolic contents of some species of the Asteraceae family from medicinal plants. Industrial Crops and Products 2019; 137(1): 208-213.
Ali, SI, Gopalakrishnan, B, Venkatesalu V. Pharmacognosy, Phytochemistry and Pharmacological Properties of Achillea Millefolium L.: A Review. Phytotherapy Research 2017; 31: 1140-1161.

Aronson JK. (Ed.) Meyler's Side Effects of Drugs: The International Encyclopedia of Adverse Drug Reactions and Interactions, Sixteenth Edition. Elsevier Science, 2016.

Ashirova ZB, Anuarova LE, Berik NT, Newsome AS, Rakhmetova AM, Yessenbekova AY, Abdrassulova ZT, Aimagambetova K. Phytochemistry of leguminous species. International Journal of Engineering and Advanced Technology 2019; 9(1): 6630-6633.

Ashirova ZZ, Kuzhantaeva ZZ, Rakhimova ZS, Abdrassulova ZT, Shaimerdenova GZ. Changes in the taxonomy based on phytochemistry of the species of the Rose family (Rosaceae). Journal of Pharmaceutical Sciences and Research 2018; 10(12): 3261-3264.

Baitenov M. Flora of Kazakhstan: an illustrated guide to families and genera (Volume 1). Almaty: Science, 2019.

Beizel NF. Atomic absorption spectrometry: Textbook. Manual. Novosibirsk State University, Novosibirsk, 2008.

El-Lakany AM, Aboul-Ela MA, Abdul-Ghani MM, Mekky H. Chemical constituents and biological activities of Cichorium intybus L. Natural Product Sciences 2004; 10: 69-73.

Evans WC. Trease and evans' pharmacognosy E-book. Elsevier Health Sciences, 2009.

Funk VA., Susanna A, Steussy TF, Robinson HE. (). Classification of Compositae. In Funk VA., Susanna A, Steussy TF, Bayer RJ (Eds.) Systematics, evolution, and biogeography of Composites, 171-189. Vienna, Austria: International Association for Plant Taxonomy (IAPT), 2009

Gaweł-Bęben K, Strzępek-Gomółka M, Czop M, Sakipova Z, Głowniak K, Kukula-Koch W. (). Achillea millefolium L. and Achillea biebersteinii Afan. hydroglycolic extracts-bioactive ingredients for cosmetic use. Molecules 2020a; 25(15): 3368.

Gaweł-Bęben K, Kukula-Koch W, Hoian U, Czop M, StrzepekGomółka M, Antosiewicz B. Characterization of Cistus $\times$ incanus L. and Cistus ladanifer L. Extracts as Potential Multifunctional Antioxidant Ingredients for Skin Protecting Cosmetics. Antioxidants 2020b, 9: 202.

Gubanov IA. Achillea millefolium L.-Yarrow. Illustrated key to plants of Central Russia. Moscow, 2004.

Hedayat KM, Lapraz J-C. Chapter 11 - Spasmophilia. In The Theory of Endobiogeny, academic Press, 2019; 155-193.

Hormozi M, Baharvand, P. Achillea biebersteinni Afan may inhibit scar formation: In vitro study. Molecular Genetics \& Genomic Medicine 2019; 7: 640.

Hussain H, Hussain J, Saleem M, Miana GA, Riaz M, Krohn K, Anwar S. 2011. Cichorin A: a new benzo-isochromene from Cichorium intybus. Journal of Asian Natural Products Research 13:566-569

Jeffrey C. Compositae: Introduction with key to tribes. In Kadereit, J.W. and Jeffrey, C., (Eds.) Families and Genera of Vascular Plants. Vol. VIII Flowering Plants, Eudicots, Asterales, Springer-Verlag, Berlin, 2007: 61-87. 
Kumari R, Ali M, Aeri V. 2012. Two new triterpenoids from Cichorium intybus L. roots. J Asian Nat Prod Res. 14:7-13

Kumari R, Ali M, Aeri V. Two new triterpenoids from Cichorium intybus L. roots. Journal of Asian Natural Products Research 2012; 14: 7-13.

Kyrbassova EA, Baitasheva GU, Danilov MP, Dyuskalieva GU, Abdrassulova ZT, Adenova BE, Saparov A. Anatomicalmorphological and phytochemical study of medicinal plant Aegopodium Podagraria L. growing in Kazakhstan. International Journal of Pharmaceutical Research 2018; 10(4): 689-697.

Lavrenova GV, Lavrenov VK. Complete encyclopedia of medicinal plants. Moscow: AST - Stalker, 2008.

Queensland Government. Weeds of Australia. Cichorium intybus. 2019. http://keyserver.lucidcentral.org.

Romm A, Hardy ML, Mills S. Botanical Medicine for Women's Health. Elsevier, 2010.

Royal Botanic Gardens, Kew and Missouri Botanical Garden. 2010. http: //www.theplantlist.org/
Satmbekova D, Srivedavyasasri R, Orazbekov Y, Omarova R, Datkhayev U, Ross SA. Chemical and biological studies on Cichorium intybus L., Natural Product Research 2018; 32:11, 1343 1347, DOI: $10.1080 / 14786419.2017 .1343319$

Shah R., Peethambaran B. Chapter 19 - Anti-inflammatory and Antimicrobial Properties of Achillea millefolium in Acne Treatment. In Chatterjee S, Jungraithmayr W, Bagchi D. Immunity and Inflammation in Health and Disease, Academic Press, 2018: 241-248.

Singh O, Khanam Z, Misra N, Srivastava M.K. Chamomile (Matricaria chamomilla L.): An overview. Pharmacognosy Reviews 2011; 5(9): 82-95. https://doi.org/10.4103/0973-7847.79103

Wu, ZY, Raven PH, Hong DY. (Eds.). Flora of China, Volume 20-21 (Asteraceae). Science Press, Beijing \& Missouri Botanical Garden Press, St. Louis, 2011.

Závada T, Malik RJ, Kesseli R. V. Population structure in chicory (Cichorium intybus): A successful US weed since the American revolutionary war. Ecology and Evolution 2017; 7(12): 4209-4219 